\title{
The Link Between Industry Value Added and Electricity Consumption
}

\author{
Gulcin Tapsin \\ Istanbul Commerce University, Faculty of Management, Department of \\ Economics, Associate Professor.
}

doi: 10.19044/esj.2017.v13n13p41 URL:http://dx.doi.org/10.19044/esj.2017.v13n13p41

\begin{abstract}
This study aims to analyse the link between industry value added and electricity consumption in Turkey for the years between 1970 and 2015. The sectoral distribution of net electricity consumption has been obtained from Turkey Electricity Distribution and Consumption Statistics on GWh basis while industry value added data have been obtained from World Development Indicators' data bases on dollar basis with the fixed prices of the year 2012. The correlations between the variables have been examined by means of Johansen cointegration test and error correction model. According to the results of the study, it has been seen that there exists bidirectional relationship between the electricity consumption and value added variable in the long term. On the other hand, in terms of the Error Correction Model used for a short-term relationship, no short-term relationship has been identified between the variables.
\end{abstract}

Keywords: Energy consumption, industry value added, Economic Growth and Productivity

\section{Introduction}

Energy consumption has vital importance for sustainable growth. The change in the economic output depends on the consumed energy, and electricity is required for all the industries to survive. This need becomes more obvious during the take-off periods of economies. The main aim in the industrial production is to obtain maximum output with minimum cost. As it is known, energy is one of the most important inputs of the production process. Gaining maximum output with each unit of consumed energy decreases the costs and increases the sectoral competitive power. In this respect, the relationship between energy consumption and output quantity has been taking the interests of the researchers to an increasing extent. 
Within the framework of this study, the relationship between the industry electricity consumption and value added was examined. While one of the indicators was the electricity used in the industry, the other one was industry value added. The annual net electrical energy used in industry was obtained from TEDAŞ (Turkish Electricity Distribution Corporation) while the annual fixed price Value Added data were obtained from World Development Indicators. In the second part of the study, the electricity consumption of Turkey's industrial sector as well as industry value added data were examined. In the third part, a relevant literature review was provided. In the following part, the data belonging to the period between 1970-2015 and the cointegration test and error correction model was presented.

\section{Industry value added and electricity consumption in turkey}

During the Third Five-Year Development Plan including the years 1973-1977, the Turkish economy grew by $6.9 \%$. Because of energy and raw material constraint that occurred as a result of 1973 world petrol crisis, the targeted growth did not come true during this period. During Third FiveYear Development Plan, some structural goals such as increasing the industry's share within GDP were determined and the industry's share within GDP increased to some extent (DPT, 1979: 7-8). 1970's were the years when Turkey's economy adopted import substitution industry and development policies.

Table 1: Electricity Consumption In Industry \% of Total and Industry Value Added \% of GDP 1970-1974

\begin{tabular}{|c|c|c|}
\hline & $\begin{array}{c}\text { Electricity Consumption In Industry \% of } \\
\text { Total }\end{array}$ & $\begin{array}{c}\text { Industry Value Added \% of } \\
\text { Gdp }\end{array}$ \\
\hline 1970 & 64,2 & 22,54 \\
\hline 1971 & 64,5 & 23,40 \\
\hline 1972 & 65,0 & 24,48 \\
\hline 1973 & 67,3 & 24,45 \\
\hline 1974 & 66,7 & 23,23 \\
\hline
\end{tabular}

During the period between 1970 and 1974, the share of industry value added within GDP showed increase until 1974 when Turkish invasion of Cyprus happened. During this period, the share of industry value added within GDP was as average about 23.62\%. After the petrol crisis, the increase rate in industry value added started to decrease, ending up with a rate of about $7.45 \%$. In 1970 , the total net amount of consumed electricity was 7,308 GWh. $64.2 \%$ of the net electricity consumption was used in industry. In 1974, the industry electricity consumption was $66.7 \%$ of the total electricity consumption. As of the end of the period, industry electricity 
consumption showed a decreasing tendency and the total industry electricity consumption of the period 1970-1974 amounted to $65.54 \%$.

Table 2: Electricity Consumption In Industry \% of Total and Industry Value Added \% of GDP 1975-1979

\begin{tabular}{|c|c|c|}
\hline & $\begin{array}{c}\text { Electricity Consumption In Industry \% of } \\
\text { Total }\end{array}$ & $\begin{array}{c}\text { Industry Value Added \% of } \\
\text { Gdp }\end{array}$ \\
\hline 1975 & 64,80 & 23,28 \\
\hline 1976 & 65,30 & 24,70 \\
\hline 1977 & 66,70 & 24,10 \\
\hline 1978 & 65,50 & 23,53 \\
\hline 1979 & 63,90 & 26,26 \\
\hline
\end{tabular}

During 1975-1979, increase in the industry value added decreased to 3.64\%. $64.8 \%$ of 1975 's total electricity of 13,492 GWh was used in industry. This rate decreased to $63.9 \%$ in 1979. During 1975-1979, compared to the previous five-year period, the industry electricity consumption decreased to about 65.24\%. During 1975-1979, the share of industry value added within GDP was about $24.37 \%$. While the industry value added increase was $7.27 \%$ in 1975 , it decreased to $-3.44 \%$ in 1979 .

Table 3: Electricity Consumption In Industry \% of Total and Industry Value Added \% of GDP 1980-1984

\begin{tabular}{|c|c|c|}
\hline & $\begin{array}{c}\text { Electricity Consumption In Industry \% of } \\
\text { Total }\end{array}$ & $\begin{array}{c}\text { Industry Value Added \% of } \\
\text { Gdp }\end{array}$ \\
\hline 1980 & 63,8 & 23,82 \\
\hline 1981 & 64,5 & 27,09 \\
\hline 1982 & 64,4 & 28,19 \\
\hline 1983 & 63,7 & 27,20 \\
\hline 1984 & 65,2 & 26,21 \\
\hline
\end{tabular}

After 1980, the import substitution model of industrialization was given up and "export-based" growth model was adopted. As a result of the narrowing domestic market, price controls and 100\% devaluation of TRY against foreign currencies, growth started to increase (Taymaz and Suiçmez, 2005). The effects of 24th January decisions on industrial production were positive. The increase in industrial production also affected GDP and hence about 5.2\% growth rate occurred during 1981-1986 (İTO, 1989: 45). During 1980-1984, the share of industry value added within GDP was about $26.50 \%$. The industry value added rate of $1980(-0.9 \%)$ increased to $10.3 \%$ in 1984. During 1980-1984, the industry value added rate increased by about $5.44 \%$. In the same year, net electricity consumption was realized as 20,398 GWh while the industry usage amounted to $63.8 \%$ of this amount. During $1980-1984$, the industry electricity consumption decreased to $64.32 \%$. 
Table 4: Electricity Consumption In Industry \% of Total and Industry Value Added \% of GDP 1985-1989

\begin{tabular}{|l|c|c|}
\hline & Electricity Consumption In Industry \% of Total & Industry Value Added \% of Gdp \\
\hline 1985 & 66,0 & 27,13 \\
\hline 1986 & 64,8 & 31,93 \\
\hline 1987 & 65,1 & 32,55 \\
\hline 1988 & 63,6 & 33,94 \\
\hline 1989 & 64,0 & 34,00 \\
\hline
\end{tabular}

As of the beginning of 1980's, the ratio of agriculture to GDP continued its downward trend and the industry production especially in the manufacturing sector gained an upward tendency (TCMB, 2002:40). During 1980-88, economic growth was observed on industry basis. When compared to import substitution period, an obvious decline was observed in the national product and industrial sector's growth rate (Eşiyok, 2006:19). During 1985-1989, the share of industry value added within GDP was $31.91 \%$. The industry value added of 1985 (7.71\%) decreased to $4.94 \%$ at the end of the period. During 1985-1989, the industry value added was $6.85 \%$ on average. $66 \%$ of the total net electricity consumption of 29,709 GWh in 1985 was consumed in industry. The industry electricity usage rate was $64.70 \%$ for the period of $1985-1989$. This rate showed increase when compared to the previous five years.

Table 5: Electricity Consumption In Industry \% of Total and Industry Value Added \% of GDP 1990-1994

\begin{tabular}{|l|c|c|}
\hline & Electricity Consumption In Industry \% of Total & Industry Value Added \% of Gdp \\
\hline 1990 & 62,4 & 32,16 \\
\hline 1991 & 57,9 & 32,69 \\
\hline 1992 & 58,4 & 32,38 \\
\hline 1993 & 57,8 & 31,10 \\
\hline 1994 & 55,6 & 33,25 \\
\hline
\end{tabular}

During 1990-1993, GDP increased by 6\% on average. However, the growth of this period displayed an instable trend because the increasing domestic demand was supported by high public deficits and short-term capital. Depending upon the stability precautions of $5^{\text {th }}$ April, domestic demand decreased to a serious extent and the GDP with fixed prices declined by 6\% in 1994 (7th Five-Year Development Plan, 1996-2000: 6). With the economic crisis of 1994, Turkey's economy experienced the biggest public and current deficit level until that time (Sönmez and Şimşek, 2011: 98-99). While the industry value added increase was $6.59 \%$ in 1990 , it decreased to $-4.96 \%$ in 1994. During the analysis period of 1990-1994, the share of industry value added within GDP was 32.32\%. During 1990-1994, the value added increase rate was realized at $3.64 \%$ on average, implying a 
serious decrease compared to the previous period. 1990 was the year when $62.4 \%$ of the total electricity consumption of 46,820 GWh belonged to industry. During the analysis period of 1990-1994, the industry electricity consumption was realized as $58.42 \%$, implying a decline compared to the previous period.

Table 6: Electricity Consumption In Industry \% of Total and Industry Value Added \% of GDP 1995-1999

\begin{tabular}{|l|c|c|}
\hline & Electricity Consumption In Industry \% of Total & Industry Value Added \% of Gdp \\
\hline 1995 & 56,4 & 33,24 \\
\hline 1996 & 54,8 & 31,60 \\
\hline 1997 & 53,1 & 31,85 \\
\hline 1998 & 52,6 & 35,34 \\
\hline 1999 & 51,0 & 33,15 \\
\hline
\end{tabular}

On the other hand, Asia and Russia's economic crises experienced in 1997 and 1998 respectively created negative outcomes on Turkey's economy (Sönmez and Şimşek, 2011: 98-99). Under these negative conditions, the industry value added rate of 1995 (8.75\%) decreased to $4.63 \%$ in 1999. The share of industry value added within GDP increased to $33.04 \%$ compared to the previous five years. $56.4 \%$ of the total net electricity consumption of 67,394 GWh in 1995 was used in industry. The industry electricity consumption of 1995-1999 was 53.8\% , implying a decline compared to the previous period.

Table 7: Electricity Consumption In Industry \% of Total and Industry Value Added \% of GDP 2000-2004

\begin{tabular}{|c|c|c|}
\hline & $\begin{array}{c}\text { Electricity Consumption In Industry \% of } \\
\text { Total }\end{array}$ & Industry Value Added \% of Gdp \\
\hline 2000 & 49,7 & 31,33 \\
\hline 2001 & 48,4 & 30,15 \\
\hline 2002 & 49,0 & 28,62 \\
\hline 2003 & 49,3 & 28,57 \\
\hline 2004 & 49,2 & 28,45 \\
\hline
\end{tabular}

In 1997 and 1998, after Asian and Russian crisis, the countries devalued their currencies to a serious amount, but Turkey did not prefer to devalue TRY against foreign currencies because of the stability program it adopted. In 1999, the country entered into a deep economic crisis. Even though IMF-supported "Exchange Rate Based Fight Inflation Program” was implemented, Turkey's economy experienced two serious financial sectorbased economic crises during 2000 and 2001 (Şimşek, 2007: 54-57). In the following years, as of the first quarter of 2002, Turkey's economy grew by about $6.5 \%$ continuously during twenty-seven quarters (Alpaydın and Tunal1, 2011: 254). In light of these developments, the share of industry 
value added within GDP was about 29.43\% during 2000-2004, which meant a decline when compared to the previous five years. While the industry value added increase rate was $6.2 \%$ in 2000, it increased to $11.6 \%$ in 2004 . The total electricity consumption that was 98,296 GWh at the beginning of the period of 2000-2004 was realized as 121,142 GWh at the end of this period. The industry electricity consumption during the whole period was $49.12 \%$ of the total electricity consumption, which implied a fall-down when compared to the previous five years.

Table 8: Electricity Consumption In Industry \% of Total and Industry Value Added \% of GDP 2005-2009

\begin{tabular}{|l|c|c|}
\hline & Electricity Consumption In Industry \% of Total & Industry Value Added \% of Gdp \\
\hline 2005 & 47,8 & 28,46 \\
\hline 2006 & 47,5 & 28,19 \\
\hline 2007 & 47,6 & 27,75 \\
\hline 2008 & 46,2 & 27,18 \\
\hline 2009 & 44,9 & 25,25 \\
\hline
\end{tabular}

During 2005-2009, the share of industry value added within GDP was about $27.37 \%$. This rate was lower than the previous period. Industry value added increase was realized as $2.98 \%$. $47.8 \%$ of the total electrical energy consumption of $2005(130,263 \mathrm{GWh})$ belonged to the industry. During 2005-2009, 46.8\% of the total electricity consumption was used in industry. This rate was lower than the previous period. After the global crisis, Turkey's economy shrinked by 4.8\% in 2009 while it showed high growth performance in 2010 and 2011. During the three-year period between 2012-2014, it grew by 3.1\%. The economy showed 3.9\% growth performance in 2015.

Table 9: Electricity Consumption In Industry \% of Total and Industry Value Added \% of GDP 2010-2015

\begin{tabular}{|l|c|c|}
\hline & Electricity Consumption In Industry \% of Total & Industry Value Added \% of Gdp \\
\hline 2010 & 46,1 & 26,39 \\
\hline 2011 & 47,3 & 27,47 \\
\hline 2012 & 47,4 & 26,67 \\
\hline 2013 & 47,1 & 26,61 \\
\hline 2014 & 47,2 & 27,10 \\
\hline 2015 & 47,6 & 26,51 \\
\hline
\end{tabular}

The share of industry within GDP is one of the most important indicators representing the industrialization level. During 1970-1999, Turkey's industry growth rate was more than GDP growth rate. During 2000's, the gap between GDP growth rate and industry growth rate decreased to a great amount. The fact that the inter-sectoral prices turned against the industry sector was one of the factors affecting the share of 
industry within GDP to decrease (Taymaz and Voyvoda, 2015: 31). During 2010-2015, the industry value added within GDP decreased to the levels of the mid-period, amounting to $26.79 \%$. While the industry value added increase rate was $13.9 \%$ in 2010, it decreased to 3.3\% in 2015. The total electricity consumption was 172,051 GWh in 2010, 46.1\% of which was used in industry. 47.11\% of the total consumed electricity of 2010-2015 was used in industry, which was higher than the average of the previous five years.

\section{Literature rewiew}

Mawejje and Mawejje (2016), analysed the long-term relationhip between electricity consumption and sectoral output in Uganda by means of vector error correction techniques. They also applied Granger Causality test in order to identify the direction of the relationship. According to the results of the study, there is a unidirectional relationship from electricity consumption to GDP and industry in the long term.

Eren Vahit M., Polat A. Melike, Aydın İbrahim H. (2016), researched the link between electricity consumption and economic growth for the period of 1975-2013 in Turkey. According to the results of the analysis, a long-term interaction was found out between the variables. It was also shown that $1 \%$ increase in the electricity consumption of Turkey also increased the growth by $0.6 \%$. Savaş and Durğun (2016), examined the long term relationship between GDP per capita and per capita electricity consumption for the period of $1980-2010$ by means of cointegration test. According to the empirical results, a long-term relation was found out between electricity consumption and economic growth. The direction of the relationship was from the growth to the electricity consumption. Danmaraya Hassan (2016), analysed the relationship between manufacturing industry efficiency and electricity consumption in Nigeria for the period of 19802013. The results show a bidirectional relationship between the variables.

Husaini and Lean (2015), analysed the relationship between output and price in electricity consumption and manufacturing sector in Malaysia. According to the results, it was seen that electricity consumption, output and prices were co-integrated in the long term and there was a positive correlation among them. In the long term, there exists a unidirectional relationship from the manufacturing industry output to electricity consumption. Kermani et al. (2015), studied the correlation between industry value added, electricity consumption and Co2 emission for the period of 1998-2011 in Iran by means of Granger Causality Test, Johansen cointegration test and Vector Error Correction Model. According to the results of Granger Causality Test, there does not exist any relationship between industry value added and electricity consumption. 
İsmiç (2015), analysed the relationship between population, economic growth and electricity consumption for eight countries listed among the developing ones according to IMF country list for the period of 1990-2012 by using Swamy's Random Coefficients Model and Seemingly Unrelated Regression (SUR) models. According to the obtained findings, it was concluded that economic growth had positive effect on electricity consumption and the population did not have any effect on electricity consumption of these two countries. Olufemi (2015), analysed the link between electricity consumption and economic growth in Nigeria for the period of 1980-2012 by means of cointegration and error correction techniques. The results indicate a positive correlation between electricity consumption and economic growth, employment and exchange rate. Teraoui (2015), examined the relationship between electricity consumption and economic growth for the period of 1980-2010 in Tunisia by means of a multivariate approach to cointegration and error correction model. According to the findings of the study, there exists a unidirectional relationship between electricity consumption and GDP in Tunisia.

Karg1 (2014), analysed the relationship between electricity consumption and GDP in Turkey for the period of 1970-2010 under the category of industry, housing and the others. The results showed that there was a co-integrating vector between GDP and industry and housing sector electricity consumption in the long term as well as a bidirectional causality relationship. Karakaş (2014), examined the national income, population and electricity consumption of twenty OECD and twenty non-OECD countries for the period of 1990-2011 through Panel data analysis. At the end of the analysis, it was seen that there was a bidirectional causality relationship between income and electricity consumption. Hepatkan and Sertkaya, surveyed the relationship between per capita electricity consumption, GDP per capita, CO2 emission and oil consumption in Turkey for the period of 1980-2014. According to the results of the study, a relationship was discovered between the series in the long term by means of co-integration analysis. The direction of the long-term relationship between the variables was examined through Granger Causality analysis. As a result, a unidirectional relationship from GDP per capita, CO2 emission and oil consumption to per capita electricity consumption was found out. Patrick (2014), surveyed the conditions affecting electricity consumption in Ghana as well as the sectors on which electricity consumption had an effect. According to the results of the study, electricity consumption had a positive effect on the manufacturing sector.

Saatçi and Dumrul (2013), examined the relationship between electricity consumption and economic growth in Turkey during the period of 1960-2008 by means of Dynamic Ordinary Least Square (DOLS) and Fully 
Modified Ordinary Least Square Method (FMOLS). The results show that electricity consumption in Turkey has an effect on economic growth. Karumba (2012), studied the correlation between electricity consumption and manufacturing industry in Kenya for the period of 1970-2008 by using VECM model. The results indicate a unidirectional relationship from the manufacturing sector output to electricity consumption. Sami (2012), analysed the long-term relationship between electricity consumption and growth in industry, trade and housing sectors in Philippines for the period of 1973-2008 by means of bounds testing procedure (2001), Johansen multivariate cointegration procedure (1988, 1990), Toda and Yamamoto tests (1995). The results indicate a long-term balance between industry sector and electricity consumption.

Kapusuzoğlu and Karan (2010), examined the long term relationship between electricity consumption and GDP in Turkey for the period of 19752006. As a result of the co-integration analysis, it was seen that there exists a long-term relationship between electricity consumption and GDP. The Granger causality analysis carried out with vector error correction model showed that there was a unidirectional causality between electricity consumption and GDP. Dilaver and Hunt (2010), analysed the relationship between industrial electricity consumption, industrial value added and electricity prices in Turkey during 1960-2008 by using structural time series technique. With this technique, they foregrounded the Universal Energy Demand Trend (UEDT) for Turkish sector. The results underline the importance of real electricity prices and UEDT in the electricity demand of Turkish industry.

Aktaş (2009), studied the relationship between electricity consumption, employment and GDP in Turkey for the period of 1970-2006 by means of Granger causality test. The study indicated a unidirectional causality relationship from economic growth and employment to electricity consumption and bidirectional causality relationship between employment and growth both in short and long term. Karagöl et al. (2007), surveyed the correlation between economic growth and electricity consumption in Turkey for 1974-2004 period through Bound Testing approach. According to this approach, a co-integration relationship was discovered and it was seen that the correlation was positive in the short term while it was negative in the long term.

Ghaderi et el. (2006), analysed the relationship between value added and electricity consumption in Iran industry. According to the results of the study, there does not exist any relationship between value added and electricity consumption in Iran's many industrial sub-sectors. Electricity consumption is only the reason of chemical, oil, metal and non-metal, transporting and measuring machined in industry. Gupta and Sahu, analysed 
the relationship between electricity consumption and economic growth in India for 1960-2006 period by means of Granger Engel causality model. The obtained findings show that electricity consumption has a positive effect on the growth. Terzi (1998), examined the Turkey's energy consumption's price and income flexibility in short/long term on sectoral basis as well as the relationship between electricity consumption and economic growth. As the results of the error correction model show, there was bidirectional causality between total electricity consumption and GDP. On sectoral level, on the other hand, bidirectional causality was identified between industry and trade electricity consumption and GDP. Nişanc1, analysed a causality relationship between electricity consumption and national income through co-integration and vector error correction models. According to the results, there is a cointegration between electricity consumption and national income as well as a unidirectional causality from electricity consumption to national income.

\section{Model}

Graph 1: Industry Value Added 1970-2015

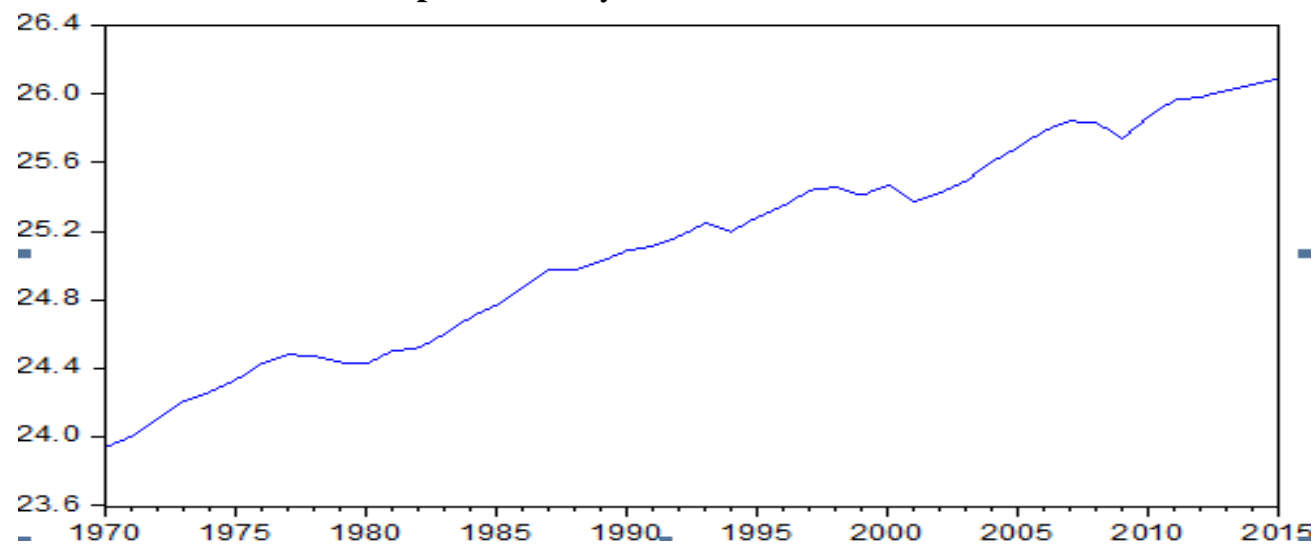

Graph 2: Electricity Consumption in Industry 1970-2015

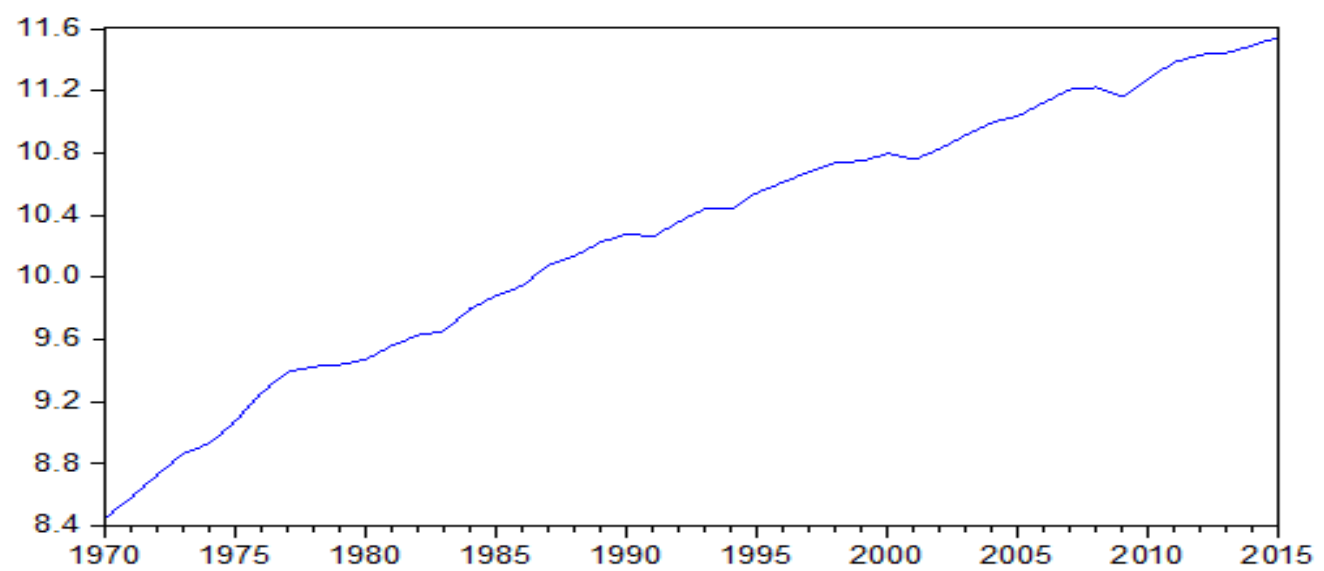


The analysis started first with the unit root tests belonging to reserve, production and consumption variables of the countries and the results of the adopted ADF unit root test are given below:

Table 10: The Results of the ADF unit root test

\begin{tabular}{ccc}
\hline Variables & Delay Number & Test statistics \\
\hline Value added & 0 & $-2.71132^{*}$ \\
Consumption & 0 & $-2.97489^{*}$ \\
$\Delta$ Value added & 0 & -3.72752 \\
$\Delta$ Consumption & 1 & -4.71373 \\
\hline \hline
\end{tabular}

Note: * shows that the unit root on the level of 5\% significance level is not rejected

When the results of the adopted ADF unit root test given in the table are examined, it is understood that Value Added and Consumption variables are not stationary. According to the results of the unit root test applied to the first differences of the variables, it is seen that these variables become stationary in their first difference.

After realizing that the variables were first-rank stationary variables, Johansen cointegration test and error correction model were used for analysing the relationship between the variables.

The cointegration tests results showing the relationship between the variables are given in the Table.

Table 11: Johansen Cointegration Test Results

\begin{tabular}{ccccc}
\hline Cointegrated Vector Number & İz Statistics & Critic value & Maximum Eigenvalue Statistics & Critic value \\
\hline Zero & $71.87050^{*}$ & 20.26184 & $66.23836^{*}$ & 15.89210 \\
Maximum 1 & 5.63213 & 9.16455 & 5.63213 & 9.16455 \\
\hline
\end{tabular}

Not: * implied that zero hypothesis is rejected at 5\% significance level.

When the results of the Table is examined, it is seen that there does not wxist a cointegrated relationship between the variables. In other words, when the zero hypothesis implying that the cointegrated vector number is zero is tested against the alternative hypothesis accepting the existence of one cointegrated vector, the zero hypothesis is rejected at $5 \%$ significance level according to both iz statistics and max-ergen statistics. It means that there is a cointegrated, namely long-term, relationship between value added and consumption variables. The obtained results indicate the existence of one cointegrated vector between the variables.

After determining the existence of one coitegrated vector, the exogeneity of the variables was tried to be identified. The results of the weak exogeneity test of the variables are presented in the Table.

Table 12: Weak Exogeneity Texts Results of the Variables

\begin{tabular}{ccc}
\hline Exogenous Variable & $\chi^{2}$ Test Statistics & Decision \\
\hline Value Added & $23.42156^{*}$ & Exogenous \\
Consumption & $53.43638^{*}$ & Exogenous \\
\hline
\end{tabular}

Note: showing that the zero hypothesis claiming that it is not weak exogenous at $5 \%$ significance level is rejected. 
Depending on the results obtained from the weak exogeneity test, it was understood that both of the variables were weak exogenous variables at $5 \%$ significance level. According to these results, one cointegrated vector, value added and consumption variables can be explained in two different ways as long-term models, where each of them is an exogenous variable. The obtained long terms models are as follows:

ValueAdded $=16.112+0.848$ Consumption
$(S E)$
(0.317) (0.030)
$t$
50.75127 .456

Consumption $=-18.990+1.178$ ValueAdded

$(S E) \quad(1.281)(0.051)$

$t \quad-14.816 \quad 23.077$

When the long-term models are examined, it is seen that the consumption variable is effective on the value added variable because the obtained $\mathrm{t}$ values are higher than the $\mathrm{t}$ table value at $5 \%$ significance level. $1 \%$ increase in consumption increases the value added by $0.84 \%$. In addition, Value Added variable has an effect on consumption. 1\% increase in Value Added increases Consumption by $1.17 \%$. On the other hand, error correction models (short-term models) could not be predicted as the delay length was determined as 0 by Akaike Information Criterion (AIC). For the short-term relationship between the variables, no results was obtained.

\section{Conclusion}

This study explains the economical effect of electricity consumption on value added basis. For this purpose, the relationship between the consumed electricity and industry value added for the period of 1970-2015 by using Johansen cointegration test and error correction model. According to the findings of the study, there does not exist a short-term relationship between industry electricity consumption and value added in Turkey while there exists a bidirectional relationship between the variables in the longterm. This result indicates that the industry development of Turkey in the long-term has increased the consumption of electricity. The increase in electricity consumption is higher than that of the industry value added. On the other hand, the results show that electricity consumption promotes an increase in industry value added in the long term. The industry electricity consumption increase is less than that of the industry value added in the long term. In this respect, it will be significant to take this close relationship into 
consideration while planning the development plans of Turkey as well as providing the required resources for the sector.

\section{References:}

1. Aktaş Cengiz (2009), Türkiye'de Elektrik Tüketimi, İstihdam Ve Ekonomik Büyüme Arasındaki İlişkinin Hata Düzeltme Modeliyle Analizi (An Analysis of Electricity Consumption, Employment and Economic Growth in Turkey through Error Correction Model), Dumlupinar University Journal of Social Sciences, No 25, pp. 61-68.

2. Alpaydın Yusuf, Tunalı Halil (2011), Türkiye İktisadının Değişimi, ITO\&ILEM, Yayın No: 2011-31.

3. 7th Five-Year Development Plan (1996-2000), http://www.surdurulebilirkalkinma.gov.tr/wpcontent/uploads/2016/06/plan7.pdf

4. Danmaraya Hassan (2016), Electricity Consumption and Manufacturing Sector Productivity in Nigeria: An Autoregressive Distributed Lag-bounds Testing Approach, International Journal of Energy Economics and Policy, 6(2), pp.195-201.

5. Dilaver Zafer, Hunt Lester C. (2010), Industrial Electricity Demand for Turkey: A Structural Time Series Analysis, Surrey Energy Economics Centre (SEEC) Department of Economics University of Surrey, Discussion Paper, SEEDS 129.

6. DPT (1979), 4th Five-Year Development Plan (1979-1983), Publication No:1664.

7. Eren Vahit M., Polat A. Melike, Aydın İbrahim H. (2016), Elektrik Tüketimi ve Ekonomik Büyüme Arasındaki İlişkinin Analizi (An Analysis of the Relationship between Electricity Consumption an Economic Growth), The Journal of Academic Perspective, No:56, pp. 275-289.

8. Eşiyok Ali (2006), İktisadi Dönemler İtibariyle Türkiye Ekonomisinde Kalkınma (Development in Turkey's Economoy Starting with Economic Periods) (1923-2004), Economic Studies, Türkiye Kalkınma Bankası A.Ş.

9. Ghaderi F. S., Azadeh A., M., Mohammadzadeh S,. (2006), Relationship Between Value Added and Electricity Consumption in the Iranian Industries, Journal of Applied Sciences 6 (2), pp. 387390.

10. Gupta Geetu, Sahu Naresh C., Causality between Electricity Consumption and Economic Growth : Empirical Evidence from India, https://www.researchgate.net/publication/44105322_Causality_betw 
een_Electricity_Consumption_Economic_growth_Empirical_Eviden ce_from_India

11. Hepaktan Erdem, Yasin Sertkaya, Türkiye’de Elektrik Tüketimi, Kişi Başına GSYİH, CO2 Emisyonu ve Petrol Tüketimi İlişkisi, Yalova University Journal of Social Sciences, Volume 6, No12, pp. 163-182.

12. Husaini Dzul Hadzwan, Lean Hooi Hooi (2015), Does electricity drive the development of manufacturing sector in Malaysia? Frontiers in Energy Research, April 2015, Vol. 3, Article 18.

13. İsmiç Betül (2015), Gelişmekte Olan Ülkelerde Elektrik Tüketimi, Ekonomik Büyüme ve Nüfus İlişkisi (The Relationship between Electricity Consumption, Economic Growth and Population in the Developing Countries), Çankırı Karatekin University İ.İ.B.F. Journal, Volume 5, No 1, pp.259-274.

14. İTO (İstanbul Chamber of Commerce) (1989), Cumhuriyet' den Bu Yana Türkiye Ekonomisinin Gelişimi ve Geleceğe Bakış (The Development of Turkey's Economy since the Foundation of the Republic and an Outlook of Future), Publication No:1989/1.

15. Kapusuzoğlu ve Karan (2010), Gelişmekte Olan Ülkelerde Elektrik Tüketimi ile Gayri Safi Yurt İçi Hasıla (GSYİH) Arasındaki EşBütünleşme ve Nedensellik İlişkisinin Analizi: Türkiye Üzerine Ampirik Bir Çalışma, (An analysis of the Cointegration and Causality Relationship between Electricity Consumption and GDP in the Developing Countries: An Empirical Study on Turkey), Volume: 1, No: 3, pp. $57-68$.

16. Karakaş (2014), OECD ve OECD Dışı Ülkelerde Elektrik Tüketimi, Nüfus ve Gelir İlişkisi: 1990-2011 Dönemi İçin Bir Panel Veri Analizi (The Relationship of Electricity Consumption, Population and Income: A Panel Data Analysis for the Period of 1990-2011), Turkish Studies - International Periodical For The Languages, Literature and History of Turkish or Turkic, Volume 9/2, ss. 845853.

17. Karagöl Erdal, Erbaykal Erman, Ertuğrul Murat H. (2007), Türkiye'de Ekonomik Büyüme ile Elektrik Tüketimi İlişsisi: Sınır Testi Yaklaşımı (The Relationship between Economic Growth and Electricity Consumption in Turkey: A Bounding Test Approach), Doğuş University Journal, 8 (1) 2007, pp. 72-80.

18. Karg1 Bilal (2014), Electricity Consumption and Economic Growth: A Long-Term Co-integrated Analysis for Turkey, International Journal of Economics and Finance; Vol. 6, No. 4, pp. 285-293. 
19. Karumba Mary (2012), The Relationship between Electricity Consumption and Output in Kenya's Manufacturing Sector, KIPPRA Discussion Paper No. 129,

20. Kaya Ayşe (2013), Mali Sürdürülebilirlik: Teori ve Türkiye Uygulamas1 (Financial Sustainability: Theory and Turkey Case), TBB (The Banks Association of Turkey, İstanbul, Publication No:292.

21. Kermani Fatemeh I., Ghasemi Mahboubeh, Abbasi Fatemeh (2015), Industrialization, Electricity Consumption and Co2 Emissions in Iran, International Journal of Innovation and Applied Studies, Vol. 10 No. 3, Mar. 2015, pp. 969-973.

22. Mawejje Joseph, Mawejje Dorothy N. (2016), Electricity consumption and sectoral output in Uganda: an empirical investigation, Journal of Economic Structures The Official Journal of the Pan-Pacific Association of Input-Output Studies (PAPAIOS)20165:21.

23. Nişancı Murat, Türkiye'de Elektrik Enerjisi Talebi ve Elektrik Tüketimi ile Ekonomik Büyüme Arasındaki İlişki (The Relationship between Turkey's Electricity Demand and Electricity Consumption and Economic Growth), SÜ The Faculty of Economics and Administrative Sciences and Social and Economic Studies Journal, pp.107-121.

24. Olufemi Ogunjobi J. (2015), The Effects of Electricity Consumption on Industrial Growth in Nigeria, Journal of Economics and Sustainable Development, Vol.6, No.13.

25. Patrick Enu (2014), Sectoral Estimation of The Impact of Electricity Consumption on Real Output in Ghana, International Journal of Economics, Commerce and Management, Vol. II, Issue 9.

26. Saatçi Mustafa, Dumrul Yasemin (2013), Elektrik Tüketimi ve Ekonomik Büyüme İlişkisinin Dinamik Bir Analizi: Türkiye Örneği (A Dynamic Analysis of the Relationship between Electricity Consumption and Economic Growth: Turkey case), Uludağ University The Faculty of Economics and Administrative Sciences Journal, Uludağ Journal of Economy and Society Vol. XXXII, No. 2, 2013, pp. 1-24.

27. Sami Janesh (2012), Sectoral Electricity Consumption and Economic Growth in Philippines: New Evidence From Cointegration and Causality Results, FNU College of Business, Hospitality \&Tourism Studies, Working Paper Series, No. 03/12

28. Savaş Bilal, Duğun Burhan (2016), Elektirk Tüketimi ile Büyüme Arasında Nedensellik İlişkisi: Türkiye Örneği (A Causality Relationhip between Electricity Consumption and Economic 
Growth: Turkey Case) Dicle University The Faculty of Economics and Administrative Sciences Journal, Year 6, Vol: 6, No:11.

29. Sönmez Asuman, Şimşek Fırat (2011), Cumhuriyetin Kuruluşundan Günümüze Türkiye Ekonomisinde Yaşanan Gelişmelerin Küçük Ölçekli Bir Aile İşletmesi Üzerindeki Etkileri (The Effects of the Developments in Turkey's Economy since the Foundation of the Republic on a Small-Scale Family Enterprise), Journal of Entrepreneurship and Development (6:2), pp. 93-114.

30. Şimşek A. Hayal (2007), Türkiye'de 2000 Sonrasında Uygulanan İstikrar Programlarının Kamu Maliyesine Etkileri, (Finance Political \& Ekonomic Remarks 2007 Vol: 44 No:512.

31. Taymaz Erol, Voyvoda Ebru (2015), 2023'e Doğru Sanayi, Yapısal Dönüşüm ve Sanayi Politikaları (Industry, Structural Transformation and Industry Policies Towards 2023), İktisat İşletme ve Finans (Economics Management and Finance), 30(350) 2015: 25-62.

32. Taymaz Erol, Suiçmez Halit (2005), Türkiye’de Verimlilik, Büyüme ve Kriz (Efficiency, Growth and Crisis in Turkey) TEK(Turkish Economic Association), Discussion Text 2005/4.

33. TCMB (2002), Küreselleşmenin Türkiye Ekonomisine Etkileri (The Effects of Globalization on Turkey's Economy), Ankara.

34. TEDAŞ (Turkish Electricity Distribution Corporation), Net Elektrik Enerjisi Tüketiminin Sektörlere Göre Dağglımı (The Sectoral Distribution of Net Electricity Consumption), http://www.tuik.gov.tr/PreIstatistikTablo.do?istab_id=1579.

35. Teraoui Hedia (2015), Relationship Between The Consumption of Electricity of Non-Renewable Origin and Economic Growth in Tunisia: Causality Analysis, The 2015 WEI International Academic Conference Proceedings.

36. Terzi Harun (1998), Türkiye'de Elektrik Tüketimi ve Ekonomik Büyüme İlişkisi: Sektörel Bir Karşılaştırma (The Relationskip between Electricity Consumption and Economic Growth: A Sectoral Comparison), Economics Management and Finance ,13(144), pp. 6271. 